\title{
PENELUSURAN ZAT TOKSIK SARANG SEMUT ACEH (Mymercodia $s p$ ) DENGAN METODE BST TERHADAP LARVA UDANG Artemia salina LEACH
}

\author{
Frengki $^{\left.i^{*}\right)}$, Cut Gina Indriyani ${ }^{2}$ \\ ${ }^{1}$ Klinik interna Fakultas Kedokteran Hewan Unsyiah, Banda Aceh \\ ${ }^{2}$ Staf pengajar Fakultas Kedokteran Unsyiah, Banda Aceh \\ *)Email: farhanayyash@gmail.com
}

\begin{abstract}
The Myrmecodia species as medicinal plants find Papua Island and Sumatera Island like Aceh forest.It is a member of Rubiaceae family and lives as ephyphyte on other plants. Local peoples in Aceh province boiled the tubers parts of myrmecodia species to treat inflammation, rheumatic,cancer and other diseases. Meanwhile, there is still limited scientific evidence to proof the efficacy of myrmecodia species. The dried simplicia was extracted using maceration technique, then partitioned usingn-hexane, chloroform and n-buthanol solvent. Toxicity test was done by the Brine Shrimp Lethality Test (BST) methodat four concentration levels, i.e: 1000, 500, 250, 125 and 6.5 ppm. The result of the research showed that $n$-buthanol, chloroform and n-hexan of Myrmecodia sphad acute toxicity by $L C_{50}$ value $97.72 \mathrm{ppm}, 262.02 \mathrm{ppm}$ and $223.87 \mathrm{ppm}$ respectively. Analysis Infrared spectrum of buthanol extract showed some functional groups. like hydroxy, aether and aromatic ring.
\end{abstract}

Keyword : Sarang semut Aceh, Toxicity, BST Methode

\section{PENDAHULUAN}

\section{Latar Belakang}

Tumbuhan merupakan salah satu bahan obat tradisional yang telah dikenal sejak dahulu kala. Dalam beberapa tahun terakhir ini penggunaan obat tradisional telah menarik perhatian dan kepopulerannya di masyarakat kita semakin meningkat.Salah satu penyebabnya adalah penerimaan masyarakat itu sendiri terhadap manfaat dan kegunaan tumbuhan obatdalam pemeliharaan kesehatan (Christine, 1985).

Pemilihan tumbuhan dalam rangka pencarian senyawa bioaktif baru dari tumbuhan dapat dilakukan melalui pendekatan secara etnobotani dan kemotaksonomi. Pendekatan etnobotani dimaksudkan penelusuran berdasarkan pemakaian bahan alam oleh suatu etnik tertentu untuk berbagai tujuan terutama pengobatan. Sedangkan pendekatan kemotaksonomi dilakukan melalui penelusuran berdasarkan hubungan kekerabatan antar tumbuhan dengan asumsi tumbuhan yang sekerabat memiliki kandungan kimia yang sama atau paling tidak memiliki rangka atau inti senyawa aktif yang sama (Anonimous, 1997).

Salah satu tanaman obat tersebut adalah sarang semut (Myrmecodia sp).Myrmecodia pendans merupakan tanaman obat asal Papua obat yang cukup ampuh mengatasi berbagai jenis penyakit terutama penyakit metabolik. Hal ini dapat dilihat dari berbagai macam laporan hasil penelitian pre-klinik maupun melalui media masa.
Subroto dan Saputro (2006), mengungkapkan bahwa senyawa aktif yang terkandung dalam sarang semut itu adalah flavonoid, tanin, dan polifenol yang berfungsi sebagai antioksidan dalam tubuh. Selain itu dalam sarang semut juga ditemukan kandungan senyawa yang bermanfaat lainnya, seperti tokoferol, magnesium, kalsium, besi, fosfor, natrium, dan seng. Senyawa aktif polifenol yang terkandung dalam sarang semut memiliki banyak khasiat,yaitu sebagai antimikroba, antidiabetes, dan antikanker.

Seiring dengan pemberitaa ntersebut, banyak ditemukan tumbuhan sejenis diberbagai daerah di Indonesia termasuk di Aceh. Penelitian dan publikasi ilmiah sarang semut Aceh masih sangat terbatas bahkan laporan khasiatnya belum ada sama sekali, padahal masyarakat di Aceh sudah lama memanfaatkan sarang semut tersebut secara tradisional sebagai obat.

Setiap penelitian bahan alam yang diduga berpotensi sebagai obat maupun secara empiris telah digunakan masyarakat sebagai obat, diawali dengan uji pre-klinis toksisitas untuk memprediksi tingkat keamanannya, kemudian dilanjutkan dengan uji farmakologi lainnya. Metode uji toksisitas dapat dilakukan secara in vitro maupun in vivo. Salah satu metode toksisitas in vitro yang sering digunakan adalah metode BST (Bhrine Shrine Test) (Alam, 2002).

BST merupakan salah satu cara yang cepat dan murah untuk skrining toksisitas dari ekstrak tanamandengan menggunakan hewan laut yaitu larva 
udang Artemia salina Leach (Meyer, 1982).Uji toksisitas dengan metode BST ini memiliki spektrum aktivitas farmakologi yang luas, prosedurnya sederhana, cepat dan tidak membutuhkan biaya yang besar, serta hasilnya dapat dipercaya. Disamping itu metode ini sering dikaitkan dengan metode penapisan senyawa antikanker.

Hasil skrining fitokimia tumbuhan sarang semut Aceh yang telah peneliti lakukan sebelumnya diketahui mengandung golongan senyawa fenol, saponin, steroid dan Triterpenoid (Frengki, dkk. 2013). Hal ini mengindikasikan tumbuhan ini kaya dengan senyawa bioaktif. Kesimpulan ini diperkuat dengan hasil uji toksisitas dengan metode BST terhadap ekstrak kasar etanol diperoleh LC $_{50}$ 61,10 $\mu \mathrm{g} / \mathrm{ml}$.

Berdasarkan latar belakang tersebut penulis berkeinginan mengetahui lebih jauh golongan senyawa aktif apa sebenarnya yang paling toksik dan berpeluang untuk dikembangkan sebagai sumber bahan baku obat dengan melakukan penelusuran berkelanjutan terhadap fraksi-fraksi yang dibedakan berdasarkan tingkat kepolarannya. Selanjutnya terhadap fraksi yang paling aktif dilakukan identifikasi kandungan senyawa kimia secara spektroskopi.

\section{MATERIAL DAN METODE PENELITIAN}

\section{A. MATERIAL}

Material yang digunakan meliputi blender, batang pengaduk, cawan petri, gelas piala $250 \mathrm{ml}-500$ $\mathrm{ml}$, gelas ukur $10 \mathrm{ml}-100 \mathrm{ml}$, seperangkat alat refluks, evaporator, toples, seperangkat alat skrinning fitokimia, sumur plat dan pipet mikro, sedangkan bahan yang digunakan adalah ekstrak etanol sarang semut, pelarut etanol 70\%, n-heksan, kloroform dan aquadest, air laut serta larva udang renik.

\section{B. METODE \\ 1. Jenis Penelitian}

Penelitian ini adalah deskripsi eksploratif dan penelitian eksperimental dengan pendekatanpost testonly control group design. Perlakuan dengan pemberian ekstraketanol, fraksi n-heksan, etilasetat dan airtumbuhan sarang semut asal Aceh terhadap larva Artemia salina Leach. Terhadap ekstrak paling toksik akan dianalisis kandungan senyawa aktifnya secara spektroskopi

\section{Populasi Dan Sampel}

Populasi penelitian eksperimental ini adalah larva Artemia salina Leach. Sampel diambil secara acak terhadap larva tang memenuhi kriteria sebagai berikut :

\section{Kriteria Inklusi:}

- Larva Artemia salina Leach berumur 48 jam

- Larva yang tidak tampak cacat secara anatomi

\section{Kriteria Eksklusi:}

- Larva Artemia salina Leach yang tidak menunjukkan aktivitaspergerakan sebelum perlakuan.

\section{Besar Sampel}

Jumlah larva Artemia salina Leach yang digunakan adalah 10 ekorlarva tiap kelompok perlakuan. Pada penelitian ini terdapat tiga kelompokperlakuan dengan lima kali replikasi untuk tiap kelompokperlakuan. Sehingga jumlah sampel total yang diperlukan adalah 150 ekor larva masingmasing ekstrak (n-heksan, kloroform, dan air).

\section{Variabel Penelitian Uji Eksperimental}

Variabel bebas dalam penelitian ini adalah ekstrak fraksi n-heksan, kloroform dan air tumbuhan sarang semut, sedangkan variabel terikat adalah efek toksikterhadap larva Artemia salina Leach.

\section{Cara Kerja \\ Pengolahan sampel}

Sarang semut di potong kecil-kecil dan dikeringkan dan di jemur di bawah paparan sinar matahari, kemudian di serbukkan dengan cara di blender.

\section{Ekstraksi sampel}

Sampel (10 kg) direndam dalam etanol 70\% dengan perbandingan 1:3 dengan sesekali dikocok. Proses perendaman ini berlangsung selama 3 hari. Kemudian dilanjutkan dengan proses penyaringan, maserat yang diperoleh diuapkan pelarutnya menggunakan rotary evaporator hingga diperoleh ekstrak kental. Selanjutnya ekstrak tersebut dimasukkan kedalam oven hingga semua air menguap dan ekstrak menjadi kering. Lakukan penimbangan terhadap rendemen yang diperoleh.

\section{Uji Toksisitas}

Pembiakan udang dilakukan dalam sebuah kotak yang telah dibagi menjadi dua bagian dengan sekat berlubang dimasukkan air laut secukupnya. Salah satu sisi kotak ditutup dengan alumunium foil, kemudian kotak diletakkan di bawah lampu UV selama 48 jam. Larva yang menembus daerah terang setelah berumur 48 jam siap digunakan untuk uji toksisitas.

Larutan induk dibuat dengan melarutkan 4 mg sampel dengan $10 \mu \mathrm{L}$ DMSO dan ditambahkan 
dengan air laut dengan kadar garam hingga $2 \mathrm{~mL}$. Kadar larutan induk adalah $2000 \mu \mathrm{g} / \mathrm{mL}$. Sampel yang akan diuji disiapkan pada konsentrasi 500, 250, 100 dan $50 \mu \mathrm{g} / \mathrm{mL}$. Sebagai blanko tanpa larutan uji dibuat dengan cara $10 \mu \mathrm{L}$ DMSO ditambahkan air laut hingga $2 \mathrm{~mL}$.

Sebanyak 10 larva udang dalam $100 \mu \mathrm{L}$ air laut dimasukkan ke dalam vial uji, kemudian ditambahkan $100 \mu \mathrm{L}$ larutan sampel. Untuk setiap konsentrasi dilakukan 3 kali pengulangan. Sebagai kontrol dilakukan dengan $100 \mu \mathrm{L}$ larutan blanko kemudian ditambahkan air laut hingga $100 \mu \mathrm{L}$. Pengamatan dilakukan setelah 24 jam dengan menghitung jumLah larva udang yang masih hidup dan yang sudah mati, kemudian dihitung mortalitasnya seperti persamaan berikut :

Nilai $\mathrm{LC}_{50}$ ditentukan melalui persamaan regresi (sumbu $\mathrm{x}$ adalah [log $\mathrm{k}$ ], sedangkan sumbu $\mathrm{y}$ adalah \% mortalitas) dengan bantuan program komputer sederhanaMic. Excel 2007. Suatu fraksi atau ekstrak dikatakan aktif bila mempunyai nilai LC $_{50} \leq$ $1000 \mu \mathrm{g} / \mathrm{mL}$ (Meyer, dkk. 1984 dan Alam. 2002).

Fraksi yang menunjukkan aktivitas daya paling toksik akan diidentifikasi kemungkinan senyawa yang dikandungnya secara deskriptif menggunakan spektrofotometer Infra Merahuntukmengetahui gugus fungsi senyawa kimia penyusunnya. SpektrumIR yang diperoleh diinterpretasikan berdasarkan pita serapan dari pola spektrum yang terbentuk.

\section{HASIL DAN PEMBAHASAN}

\section{A. Hasil}

Hasil partisi 1,8 g ekstrak etanol sarang semut diperoleh masing-masingnya fraksi heksan 100mg, fraksi kloroform $300 \mathrm{mg}$, dan fraksi butanol sebanyak $1,4 \mathrm{~g}$.

Hasil uji BSLT diperoleh nilai $\mathrm{LC}_{50}$ masingmasing fraksi tersebut sebesar 223.87 ppm untuk fraksi heksan, 26.02 ppm untuk fraksi kloroform, dan 97.72 ppm untuk fraksi butanol.

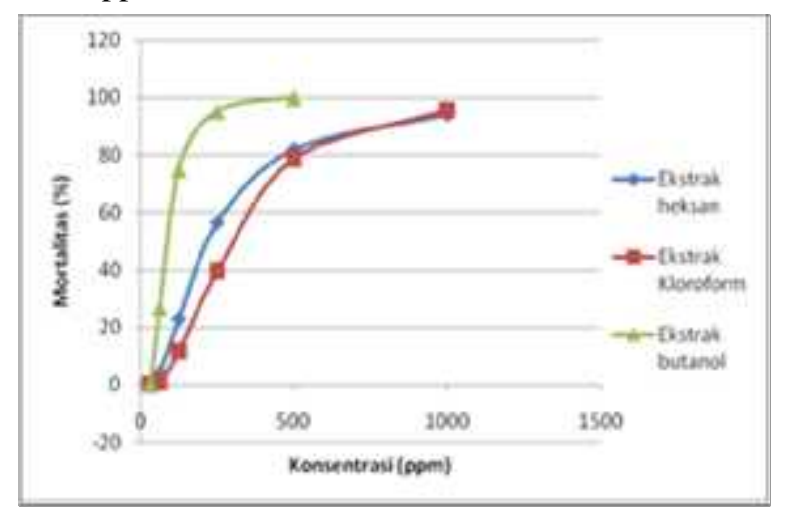

Gambar 1. Grafik Hasil Uji BST
Hasil identifikasi gugus fungsi fraksi butanol diketahui adanya pita serapan pada bilangan gelombang (v) 962.27, 1068.56, 1099.43, 1280.73,

$1442.75, \quad 1510.28, \quad 1602.87, \quad 2050.33$, $2277.93, \quad 2382.09, \quad 2717.70, \quad 2931.80, \quad 3066.82$, $3122.75,3176.763496 .94,3550.95$ dan $3603.03 \mathrm{~cm}^{-1}$

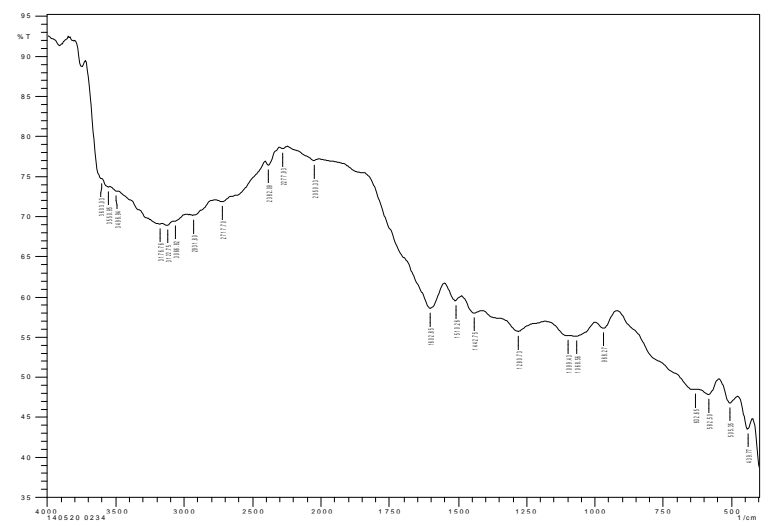

Gambar 2. Grafik FT-IR ekstrak butanol

\section{B. Pembahasan}

Hasil partisi menunjukkan fraksi polar (nbuthanol) merupakan komponen terbanyak yang terdapat dalam ektrak etanol sarang semut yaitu sebesar 77,78\%, selanjutnya fraksi semi polar (kloroform) dengan persentase $16,67 \%$ dan terakhir fraksi non polar (n-hexan) 5,56\%.

Komponen yang terkandung dalam fraksi polar diduga senyawa golongan polifenol dan glikosida. Hasil skrining uji fitokimia yang telah telah peneliti laporkan sebelumnya (Frengki dkk, 2013) dengan metode Simes dkk (1995) yang dimodifikasi, positif mengandung fenol dan saponin (glikosida). Senyawa golongan fenol ditandai terjadinya perubahan warna endapan ekstrak uji menjadi biru setelah diteteskan $\mathrm{FeCl}_{3}$, sedangkan indikasi adanya senyawa golongan glikosidamelalui pengocokan kuat secara vertikal selama 10 detik campuran sedikit ekstrak sarang semut dengan air didalam tabung reaksi membentuk busa setinggi $1-10 \mathrm{~cm}$ yang stabil kurang lebih 15 menit dan tidak hilang pada penambahan setetes asam klorida $2 \mathrm{~N}$.

Informasi ini diperkuat berdasarkan interpretasi spektrum infra merah (FTIR) yang menunjukkan pita serapan pada bilangan gelombang (v) $3496.94,3550.95$ dan $3603.03 \mathrm{~cm}^{-1}$ yang menunjukkan vibrasi ulur gugus-O-H. Pita serapan dengan bilangan gelombang (v) 3122.75 dan 3176,76 $\mathrm{cm}^{-1}$ menunjukkan gugus aromatis (vibrasi ulur $\mathrm{C}-\mathrm{H}$ aromatis) dan $1602.85 \mathrm{~cm}^{-1}$ (vibrasi ulur $\mathrm{C}=\mathrm{C}$ aromatis). Adanya puncak serapan pada bilangan gelombang $v$ : 2931.80, 3066.82, dan $3122.75 \mathrm{~cm}^{-1}$ menunjukkan adanya vibrasi ulur dari C-H. Adanya pita serapan pada daerah bilangan gelombang $v$ : 
1068.56, 1099.43, dan $1280.73 \mathrm{~cm}^{-1}$ menunjukkan adanya ikatan C-O-C (Khopkar SM. 1990, Larry G Hargis. 1988)

Hasil uji BSLT (Brine Shrime Letality Test) menunjukkan ketiga fraksi hasil partisi tersebut bersifat toksik. Sebagaimana dikemukan Meyer dkk (1984) dimana suatu ekstrak yang berasal dari bahan alam dikatakan toksik jika nilai mortalitas $\left(\mathrm{LC}_{50}\right)<$ $1000 \mathrm{ppm}$. Informasi ini dapat pula diterjemahkan bahwa sifat toksik tersebut berasal dari komponen bioaktifnya. Lebih jauh metode BSLT ini sering dihubungkan dengan potensi ekstrak tersebut sebagai antikanker.

Dari ketiga fraksi tersebut ternyata fraksi polar yang paling kuat daya toksiknya yaitu 97,72 ppm. Sedangkan fraksi semi polar dan fraksi non polar masing-masingnya 262,02 ppm dan 223,87 ppm. Perbedaan daya toksik tersebut diduga komponenkomponen senyawa aktif yang dikandung masingmasing fraksi berbeda satu sama lain. Komponen senyawa aktif fraksi polar diduga lebih kuat ketimbang dua fraksi lannya. Selain itu karena jumlah komponen senyawa aktif yang dimiliki fraksi polar lebih banyak ketimbang fraksi semi polar maupun non polar.

Berdasarkan hasil partisi dan uji BSLT tersebut dapat diamati kemungkinan senyawa aktif yang potensial ditelusuri adalah fraksi polar. Potensi fraksi ini larut dalam air juga lebih besar sehingga dapat dimengerti pengolahan sarang semut ini secara tradisional oleh masyarakat melalui teknik perebusan, seduhan menghasilkan efek terapi yang signifikan baik terhadap penyakit akut yang sering diderita seperti flu dan batuk juga terhadap penyakit kronis seperti hiperkolesterol, diabetes, asam urat hingga penyakit kanker.

\section{DAFTAR PUSTAKA}

Alam, G. 2002. Brine Shrimp Lethality Test (BSLT) Sebagai Bioassay dalam Isolasi Senyawa Bioaktif dari Bahan Alam. Majalah Farmasi dan Farmakologi. 6(2). 432-435.

Anonimus. 1997. Tumbuhan Hutan Tropik Sebagai Sumber Bahan Kimia. Bogor : Puslitbang Biologi LIPI. 5-11.

Christine. 1985. Penggunaan Tanaman Obat. Penerbit Buletin Farmakon, Jakarta.

Frengki., Wati., R, Pertiwi, D. Uji toksisitas Ekstrak Etanol Tumbuhan Sarang Semut Aceh (Myrmecodia sp) dengan metode BSLT. Jurnal Veterinaria Medika. Vol 7. No.2 FKH-Unsyiah. Banda Aceh
Khopkar SM. 1990. Konsep Dasar Kimia Analitik. Jakarta : UI Press.

Larry G Hargis. 1988. Analytical Chemistry. Principles And Technigues. NewJersey : Prentice Hall Inc

Meyer, B.N. 1982. "Brine Shrimp : A Convenient General Bioassay for Active Plant Constituents". Journal of Medical Plant Research Planta MedicaUSA. 31-34

Simes, J.J.H., J.G. Tracey, L.J. Webb, and W.J. Dunston. $1995 . \quad A n$ Australian PhytochemicalSurvey, Commonwealth Scientific and Industrial Research Organization, Australia.

Subroto, A. dan Saputro, H. 2006. Gempur Penyakit Sarang Semut. Penerbit Swadaya, Depok. 